\title{
Factors affecting financial management: Case study of educational manager training and foster-
} ing public institutions

\author{
Thang Quyet Nguyen ${ }^{a}$, Ha Thanh Viet ${ }^{b}$ and Le Thi Thanh Loan ${ }^{b}$
}

${ }^{a}$ Ho Chi Minh City University of Technology (Hutech), Vietnam

${ }^{b}$ Ho Chi Minh City School of Educational Administration, Vietnam

\section{H R O N I C L E}

\section{Article history:}

Received: November 18, 2020

Received in revised format:

December 282020

Accepted: January 20, 2021

Available online:

January 20,2021

Keywords:

Financial reporting system

Financial management

Managers training and fostering

institutions

Ho Chi Minh City

\section{A B S T R A C T}

The research focuses deeply on and evaluates the factors affecting financial management of educational managers training and fostering institutions in Ho Chi Minh City, Vietnam. This is a very specific model for countries in transition economies as in Vietnam, a country is in the process of comprehensive renovation, restructuring public service delivery institutions, increasing the assignment of self-responsibility to institutions, reducing financial pressure on the State budget. Using qualitative and quantitative research methods together with techniques, i.e., testing reliability scales with Cronbach's alpha coefficients, exploratory factor analysis EFA, CFA and linear model SEM, the study investigated 500 samples in 07 educational institutions in Ho Chi Minh City, Vietnam. The findings revealed six (06) factors, which are internal control system, technology infrastructure, top managers' commitment, cash management and budget system, organizational responsibility, affected the financial reporting system, and meanwhile, the financial reporting system has a positive impact on the financial management. Based on this result, the study has proposed implications for improving financial management in educational managers training and fostering institutions in $\mathrm{Ho}$ Chi Minh City, Vietnam.

\section{Introduction}

Financial management is one of the essential contents in improving management efficiency in a unit in the public sector (Chado, 2015). In Vietnam, since the 1980s of the twentieth century, in the transition of the economic management mechanism from the "central planning" mechanism to the market economy, the financial management of public professional career institutions such as hospitals, colleges, universities, etc. have been comprehensively changed, from State budget based to financial autonomy model (National Assembly of Vietnam, 2015). Earlier in Vietnam, State professional career institutions are units functioning in provision of public goods and services for society, and other public goods and services in the fields of education, health, culture and information ... such as vocational institutions, colleges, universities, theaters, sports centers, etc., are all in-line budgets funded by the State. Since 2015, public professional career institutions have, so far, gradually shifted to the model of financial autonomy, autonomy in self-collecting revenues and spending of their activities. The system of educational manager training institutions is a place for training administrators, civil servants and State employees in the fields of education. The main task of these educational manager training institutions is to train and foster managerial cadres and public servants and professional core for educational authorities and educational institutions. This is a specific model for countries in transition economies such as Vietnam. Currently in Vietnam, educational administrator training and fostering institutions exist in various sectors i.e., health, education, finance, etc., which are all under either ministerial control or local authorities. Particularly, the system of educational administrator training and fostering institutions in the field of education under the Ministry of

* Corresponding author.

E-mail address: nq.thang@hutech.edu.vn (T. Q. Nguyen) 
Education and Training currently comprises 49 institutions which are tasked with providing professional training activities and granting certificates for educational administrators in educational authorities and management institutions. In Ho Chi Minh City, there are 07 institutions assigned the function of training and fostering education managers at all levels. In 2019 , these institutions have provided training activities to more than 2,000 turns of educational administrators in Ho Chi Minh City and localities nation-wide (Department of Education and Training of Ho Chi Minh City, 2019) contributing positively to the development of the educational managerial staff in Vietnam. In Vietnam, there exists few studies related to financial management in educational institutions in regardless of the following studies i.e., Minh \& Huy (2018); Manh \& Thao (2019); The Vietnamese Ministry of Finance (2017), etc., which discussed theoretical issues in financial management in public universities in Vietnam. In a specific view of quantitative research works on this issue, there are hardly any studies related to financial management of public professional career institutions in Ho Chi Minh City.

\section{Literature review and research hypotheses}

\subsection{Literature review}

Financial resources are an important resource of organization. No organization has ever been successful without financial resources (Allis, 2004). Therefore, organizations must focus on financial management to enhance their financial resources and reduce risks. Globally, financial management has been studied by various scholars. According to Eton et el. (2018) the rationale for financial management is raising funds for both short-term and long-term use and enhancing proper utilization of the funds. Allen and Tommasi (2001) argued that financial management is to make financial activities aim to be accomplished with high efficiency. Financial management includes revenue, management and control of public spending, financial reporting, cash management and asset management. Well-designed financial management is the management tool that provides a wealth of non-financial and financial information of the organization (Diamond \& Khemani, 2006). Chêne (2009) and Bhatia (2003) in Government Operations, Financial Management also refers to the computerization of public financial management processes, from budget preparation and implementation to accounting and reporting, with the help of an integrated system for financial management purposes. There have been a number of studies regarding the influencing factors to financial management and its related aspects. Ahmed, Babar \& Kashif (2010) have conducted a study on practical financial management to measure the relationship between organizational performance and finance, management practices such as capital structure, dividend policy, technical investment appraisal, working capital management and financial performance evaluation in Pakistan. Wangari \& Muturi (2017) found the effects of financial management practices on the performance of public universities in Kenya through the following factors: (i) annual budget adherence, (ii) financial monitoring, (iii) investment decision and financial planning, etc. Afiah and Azwari (2015) found a link between financial management and the organization's financial reporting system.

An honest and healthy reporting system requires strengthening internal control system (Afiah \& Azwari, 2015). Muda et al., (2017) find the positive impact of technology infrastructure on the financial reporting system of public sector units, thereby affecting financial management of organizations. Other studies have found such factors as the impact relationship between top management commitment (Diamond \& Khemani, 2006; Mwakio, 2015); Human resource development (Diamond \& Khemani, 2006; Leiderer et al., 2007) also positively affects the financial reporting system and financial management of the organization. Diamond \& Khemani (2006) report that in Tanzania, as the level of transparency and accountability increases, the efficiency of financial management in these entities also increases by improving control over spending, by the cost and performance of the entity. Research results of Chado (2015) shows a positive relationship between financial reporting systems and financial management in public entities. For Vietnam, the report conducted by the Ministry of Finance of Vietnam (2017) revealed an assessment of the financial management in public public professional career institutions in Vietnam, it is said that the Financial Reporting System has a great influence on the financial management and the system is affected by factors such as: internal control system, technological infrastructure, top management commitment, cash management and system budget system, organizational responsibility

\subsection{Development of hypotheses}

\subsubsection{Internal control system}

According to COSO (2013) internal control is the process influenced by the organizational leadership, management and other personnel, designed to reasonably ensure that the organization's goals will be achieved, it affects the financial reporting system from which this system in turn influences the financial management at the institutions. Internal controls include: Control environment, risk assessment, control activities, information and communications, and monitoring. Afiah and Azwari (2015) explains that ineffective internal control degrades the quality of financial statements, thereby affecting financial management. According to Nunuy Nur Afiah et al. (2015) the implementation of the internal control system in the public sector units has a positive and significant impact on the financial reporting system and from there on the management. Therefore, improving the internal control system of public institutions becomes a very important part of ensuring the quality of financial management in corporate governance. The hypothesis could be: 
Hypothesis $\mathbf{H}_{1}$ : The internal control system has a positive impact on financial management at the unit.

\subsubsection{Technology infrastructure}

The development of accounting information technology in an organization has a real impact on data processing from manual systems to computer systems and the emergence of accounting software will make financial management of the unit easier. Technological infrastructure is related to the physical infrastructure of the organization. The study established that financial mismanagement had adversely affected physical facilities (Mobegi, 2015). Iskandar Muda (2017) found a positive effect of technology infrastructure on central and local government financial reporting systems in Labuhanbatu Regency, Indonesia. According to this author, the obligation to use information technology of central and local governments has been set forth in the government's regulation for public sector financial information systems and this contributes to increased improvement in the quality of financial management of these units. The hypothesis could be:

Hypothesis $\mathbf{H}_{2}$ : Technology infrastructure has a positive impact on financial management.

\subsubsection{Commitments of top managers}

Diamond \& Khemani (2006) who studied financial management information systems in developing countries, show that one of the reasons for failure in financial management is that senior managers are rarely delegated, assigning responsibilities to subordinates to participate in financial management, management lacks accounting experience and therefore cannot grasp the financial situation, financial management as well as limited in the use of reports. Financial statements for executive decision making. Commitment by senior management to contribute to the implementation and formulation of goals and to describe the application of information systems in general and accounting information systems in particular is seen as a figure. management's active involvement in this information system. Top management's commitment and support to the successful implementation of an accounting information system also includes a willingness to provide the necessary resources and authority to implement the system (Mukkamala, 2013). Mwakio (2015), investigating the challenges faced by the authorities in implementing financial management in Taita Taveta district, the research results show that senior management officials are too busy with professional work, they do not participate in financial management training, so top managers are still very limited in their ability to manage finance. The hypothesis could be:

Hypothesis $\mathbf{H}_{3}$ : Commitments of top managers have a positive impact on financial management.

\subsubsection{Human resource development}

Odoyo, Adero \& Chumba (2014) said that in order to build a good governance, the first thing to pay attention to is human resources capacity of the organization; the better the quality of human resources used, the better performance results will help achieve the goals of the organization, including those related to accounting, to the financial management system of the organization. According to Diamond \& Khemani (2006) human resources professionals must have the right preparation and experience, this team is not only for provision effective support to an organization's mission, but also for engaging as partner with managers and employees in the development, implementation and evaluation of the organization's human resource and human resource development approaches. According to Leiderer et al., (2007) when the value of people in the organization increases, the efficiency of the organization also increases. In addition, the policy on human capital, human resource development of the organization must be engaged to support achieving the organization's goal (Nguyen \& Giang, 2020). Human resource capacity is the ability of human resources to perform assigned tasks and responsibilities with the support of education, training and complete experience (Sanches, Marin \& Morales, 2015). Competent human resources will be able to understand the logic of accounting, which in turn can perform their jobs better, and improve the quality of the financial reporting system they build. Therefore, human resource capacity has a positive and significant influence on the quality of local government's financial reports. The hypothesis could be:

Hypothesis $\mathbf{H}_{4}$ : Human resource development has a positive impact on financial management.

\subsubsection{Cash management and budgeting system}

Dorotinsky et al., (2003) argued that an entity's financial management can be improved by increasing the reliability of reports through information integrity and transparency such as reports on budget and cash. Odoyo et al., (2014) in investigation of financial management at Eldoret West County Treasury, Kenya through cash management, found out that effective cash management has a positive impact on financial management of the organization. Research results of Chado (2015) argued that security, reliability, macroeconomic forecasts, budget preparation and approvals affect financial management in the public sector. The hypothesis could be:

Hypothesis $\mathbf{H}_{5}$ : Cash management and the budgeting system have a positive impact on the financial management system. 


\subsubsection{Organizational responsibility}

A study by Diamond \& Khemani (2006) reports that in Tanzania, as transparency and accountability increase, the efficiency of financial management in these entities also increases by improving expenditure control, balancing cost and performance of the organization. Findings from the research of Chado (2015) argued that organizational responsibility relates to aspects such as responsibility to track financial events, availability of information, analysis of organizational costs and responsibility for disclosure. information affecting financial management in the public sector. The hypothesis could be:

\section{Hypothesis $\mathbf{H}_{6}$ : Organizational responsibility has a positive impact on the financial reporting system.}

\subsubsection{Financial reporting system}

Thurakam et al., (2007) found that in order to achieve an organization's objectives, financial reporting must be of quality, reliable, timely, relevant and understandable. Simson et al., (2011) argued that extracting and presenting data from an accounting system must facilitate analysis of the financial management of the unit. Research results of Chado (2015) shows that the financial reporting system has a significant effect on financial management in the public sector, aspects of financial reporting such as security, reliability, accuracy, timeliness, relevance and honesty have affected financial management in the public sector. Comments of the Ministry of Finance of Vietnam (2017) also said that the financial reporting system directly affects the financial management of the unit. The hypothesis could be:

Hypothesis $\mathbf{H}_{7}$ : The financial reporting system has a positive impact on financial management.

Based on the theories related to financial management of Nurillah (2014), Diamond \& Khemani (2006), Mwakio (2015), Chado (2015) and some other studies, this research has been discussed with 12 experts to build the research model as follows:

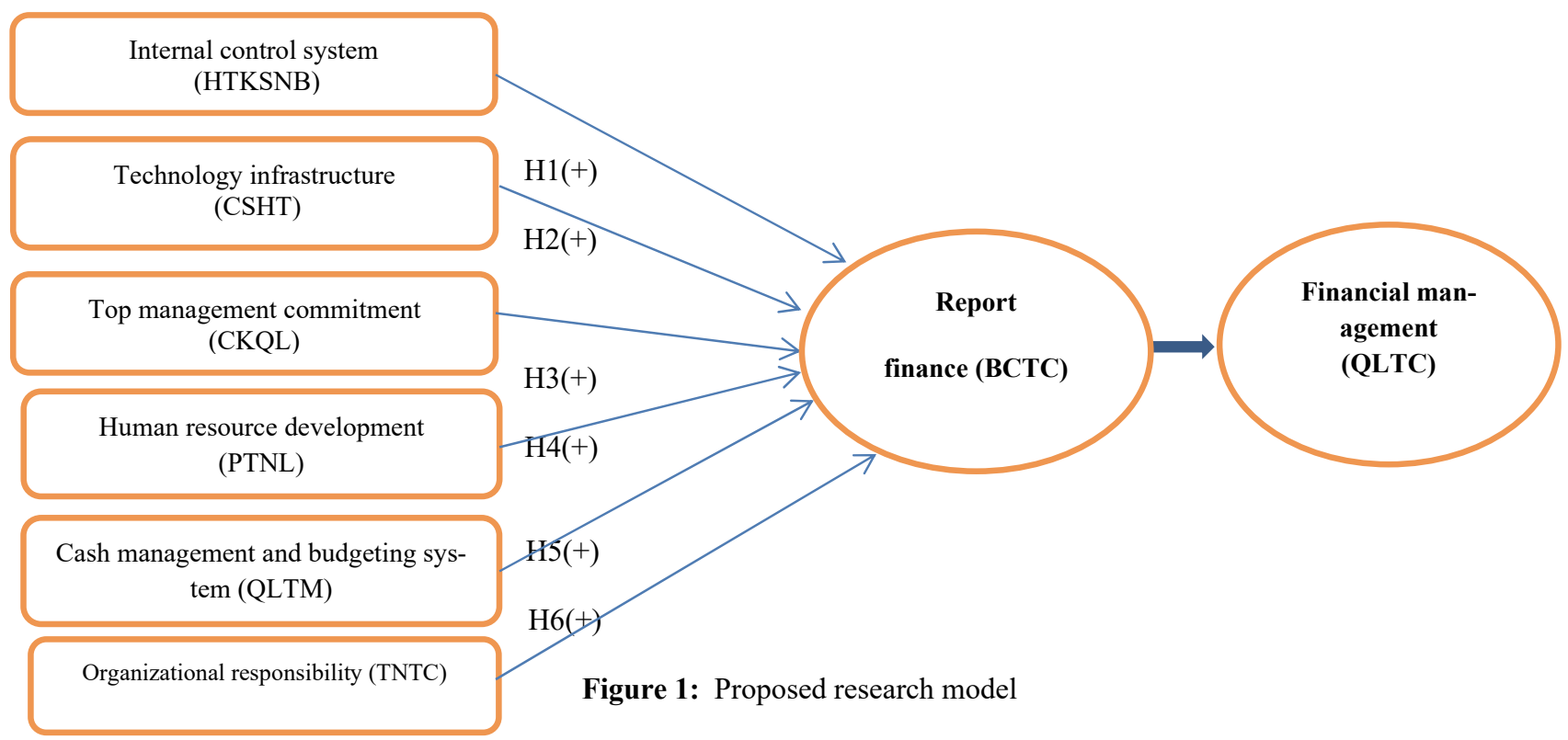

\section{Research Methods}

This study uses a three-stage approach.

Phase 1, in this stage, the author conducted brief reviews and considered other studies relating to the topic of financial management. Next, the study interviewed in-depth with 12 experts to correct the proposed research model. The study conducted a preliminary survey with 200 people working in training institutions and fostering for educational administrators in Ho Chi Minh City, Vietnam to check the clarity and comprehension of the previous questionnaire. when put into practice for an official survey. The author continued conducting preliminary quantitative research with 200 samples and continues to adjust the questionnaire before the official study.

Phase 2, in this phase, the following activities were performed: Testing the reliability of the scale with Cronbach's Alpha coefficients and exploratory factor analysis. According to those observed variables with the total correlation coefficient greater than 0.3 and Cronbach's Alpha coefficient greater than 0.6 to ensure the reliability of the scale. The purpose of exploratory factor analysis is to shrink and summarize the data. This method is based on the factor extraction ratio (Eigenvalue), factor 
analysis is appropriate and the observed variables in the population are correlated when the total variance extracted must be $>$ $50 \%$, the KMO coefficient lies. in the range 0.5 to 1 , the coefficient $\mathrm{Sig}$. $\leq 5 \%$, the Factor loading of all observed variables is $>0.5$; weight difference $\lambda \mathrm{iA}-\lambda \mathrm{iB}$ are $>0.3$ (Nguyen Dinh Tho, 2011).

Phase 3: Two contents in this phase are (1) CFA confirmatory factor analysis and (2) Test a research model by analyzing SEM (Structural Equation Modeling) linear models. The purpose of CFA affirmative factor analysis helps to clarify: (1) Unidirection; (2) The reliability of the scale; (3) Convergence value; (4) Distinguishing value. According to Steenkamp and Van Trijp (1991); Hair et al., (2010), a research model that is considered consistent with market data if the Chi-quare test has P-value $>5 \%$; CMIN / df $\leq 2$, in some cases CMIN / df can be $\leq 3$ (Carmines and McIver, 1981); GFI, TLI, CFI $\geq 0.9$. However, according to the recent opinion of researchers, GFI is still acceptable when it is greater than 0.8 (Hair et al., 1998); RMSEA $\leq 0.08$. In addition to the above criteria, the test results must also ensure the general reliability $>0.6$; The extracted variance must be greater than 0.5 (Hair et al., 2010).

All data collected from the questionnaire were coded and processed using SPSS and AMOS software.

\section{Research findings}

\subsection{Descriptive statistics on the sample}

The sampling of the study is taken according to Hair et al., (2010). The minimum sample size must be $\geq \mathrm{m} \times 5$, where $\mathrm{m}$ is the number of observed variables. With 40 observed variables in this study, the minimum sample size must be $\geq 200$ samples. The study conducted a formal survey of participants including: educational institution 's leaders who are in charge of finance; Chief Financial Officer; chief accountant; leaders of faculties, institutes, and centers in institutions; lecturers and specialists in the finance, accounting and internal control departments of the 07 institutions for training and fostering education managers in Ho Chi Minh City, Vietnam. These people are professional and knowledgeable about financial management. To ensure reliability, the number of questionnaires distributed was 550 questionnaires; the number of votes was 508 . Out of 508 collected questionnaires with 500 valid votes used as data for quantitative research, invalid votes were removed from the study because the respondents did not either answer all of the survey contents or selected many options for the same statement.

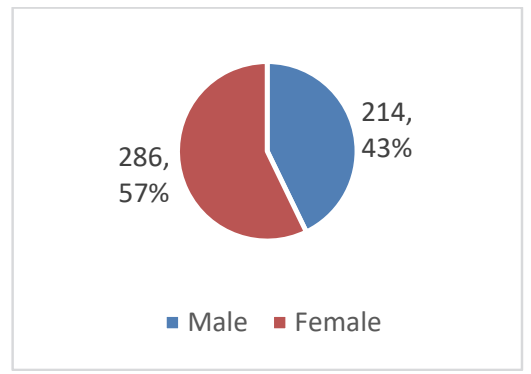

Gender

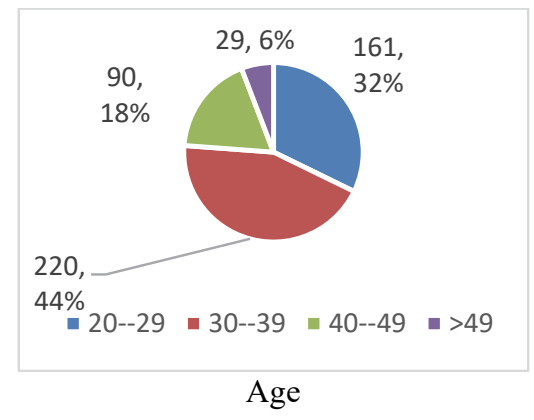

Fig. 2. Respondents' demographic profile

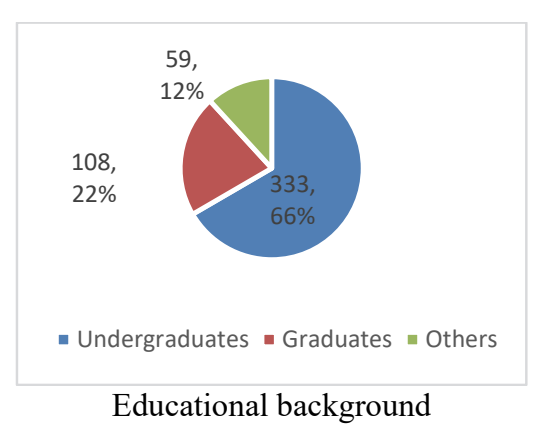

Educational background

Among 500 surveyed objects, female respondents accounted for 57.2\% while male ones accounted for 42.8\%. About age, number of people at age ranging from 20 to 29 accounting for $32.2 \%$, and respectively $44,0 \%$ (from 20 to 29 ), and $18,0 \%$ (40 - 49), 5,8\% (over 50 years old).

\subsection{Explore factor analysis EFA}

EFA is suitable when the conditions are satisfied: $0.5 \leq$ Kaiser - Meyer - Olkin (KMO) value $\leq 1$ and sig $<0.05$ (the observed variables are correlated with each other). The value of KMO must be at least 0.5 or more to qualify for analysis and the closer the $\mathrm{KMO}$ value is to 1, the more appropriate the discovery factor analysis is (Meyers, Gamst, \& Guarino, 2013).

\subsection{Confirmed Factors Analysis}

CFA is applied using the degrees of freedom adjusted Chi-squared (CMIN), degrees of freedom (CMIN / df), comparative relevance index (CFI), Tucker and Lewis Index. (TLI-Tucker and Lewis Index) and RMSEA (Root mean square error approximation). The model is considered appropriate when the Chi-square test has $\mathrm{p}<5 \%$, GFI, TLI, CFI $>0.9$ (Bentler \& Bonett, 1980), CMIN / df $\leq 2.0$ test (in some fields. The values of CMIN / df $\leq 3.0$ are also accepted (Carmines \& Mcver, 1981) and RMSEA $\leq 0.08$, RMSEA $\leq 0.05$ are also accepted (Steiger, 1990). CFI $\geq 0.9, \mathrm{CMIN} / \mathrm{df} \leq 2.0, \mathrm{RMSEA} 0.08$ is accepted (Tho $\&$ Trang, 2011). GFI $\leq 0.9$ is still accepted (Hair et al., 2010). 
Table 1

Explore factor analysis EFA

\begin{tabular}{|c|c|c|c|c|c|c|c|c|c|c|c|}
\hline \multirow{2}{*}{ Code } & \multicolumn{8}{|c|}{ Factors } & \multirow[t]{2}{*}{$\boldsymbol{\alpha}$} & \multirow[t]{2}{*}{ Corrected } & \multirow[t]{2}{*}{$\alpha$ if } \\
\hline & 1 & 2 & 3 & 4 & 5 & 6 & 7 & 8 & & & \\
\hline HTKSNB4 & .840 & & & & & & & & \multirow{6}{*}{.899} & .799 & .870 \\
\hline HTKSNB3 & .834 & & & & & & & & & .776 & .875 \\
\hline HTKSNB2 & .826 & & & & & & & & & .784 & .873 \\
\hline HTKSNB1 & .799 & & & & & & & & & .731 & .881 \\
\hline HTKSNB5 & .766 & & & & & & & & & .733 & .881 \\
\hline HTKSNB6 & .691 & & & & & & & & & .557 & .906 \\
\hline CSHT4 & & .846 & & & & & & & \multirow{4}{*}{.870} & .752 & .822 \\
\hline CSHT3 & & .827 & & & & & & & & .722 & .835 \\
\hline CSHT2 & & .798 & & & & & & & & .729 & .832 \\
\hline CSHT1 & & .768 & & & & & & & & .700 & .845 \\
\hline CKQL 2 & & & .810 & & & & & & & .686 & .791 \\
\hline CKQL 1 & & & .797 & & & & & & & .659 & .805 \\
\hline CKQL 4 & & & .795 & & & & & & & .667 & .801 \\
\hline CKQL 3 & & & .789 & & & & & & & .688 & .790 \\
\hline PTNL 2 & & & & 805 & & & & & \multirow{4}{*}{.840} & .650 & .725 \\
\hline PTNL 3 & & & & 805 & & & & & & .647 & .728 \\
\hline PTNL 1 & & & & 782 & & & & & & .612 & .745 \\
\hline PTNL 4 & & & & 726 & & & & & & .531 & .784 \\
\hline QLTM2 & \multicolumn{8}{|c|}{.885} & & .786 & .807 \\
\hline QLTM3 & \multicolumn{8}{|c|}{.859} & & .749 & .840 \\
\hline QLTM1 & \multicolumn{8}{|c|}{.856} & & .758 & .832 \\
\hline TNTC2 & & & \multicolumn{6}{|c|}{.866} & \multirow{3}{*}{.878} & .666 & .558 \\
\hline TNTC3 & & & \multicolumn{6}{|c|}{.820} & & .605 & .632 \\
\hline TNTC1 & & & \multicolumn{6}{|c|}{.732} & & .470 & .777 \\
\hline НТВСТC6 & & & & & \multicolumn{4}{|c|}{.840} & \multirow{6}{*}{.873} & .741 & .840 \\
\hline НТВСТС2 & & & & & \multicolumn{4}{|c|}{.839} & & .745 & .838 \\
\hline НТВСТC5 & & & & & \multicolumn{4}{|c|}{.789} & & .683 & .850 \\
\hline НТВСТC3 & & & & & \multicolumn{4}{|c|}{.772} & & .666 & .853 \\
\hline НТВСТC1 & & & & & \multicolumn{4}{|c|}{.764} & & .652 & .857 \\
\hline НТВСТC4 & & & & & \multicolumn{4}{|c|}{.696} & & .578 & .868 \\
\hline QLTC2 & & & & & & & & .885 & \multirow{6}{*}{.840} & .791 & .783 \\
\hline QLTC3 & & & & & & & & .844 & & .756 & .790 \\
\hline QLTC1 & & & & & & & & .834 & & .725 & .800 \\
\hline QLTC5 & & & & & & & & .805 & & .694 & .803 \\
\hline QLTC4 & & & & & & & & .787 & & .662 & .807 \\
\hline QLTC6 & & & & & & & & .709 & & .582 & .819 \\
\hline Eigenvalues & & & & & & & & 1.379 & & & \\
\hline Bartlett's test & KMO & & & & & & & .851 & & & \\
\hline Bartiet s test & Sig. & & & & & & & 0.00 & & & \\
\hline
\end{tabular}

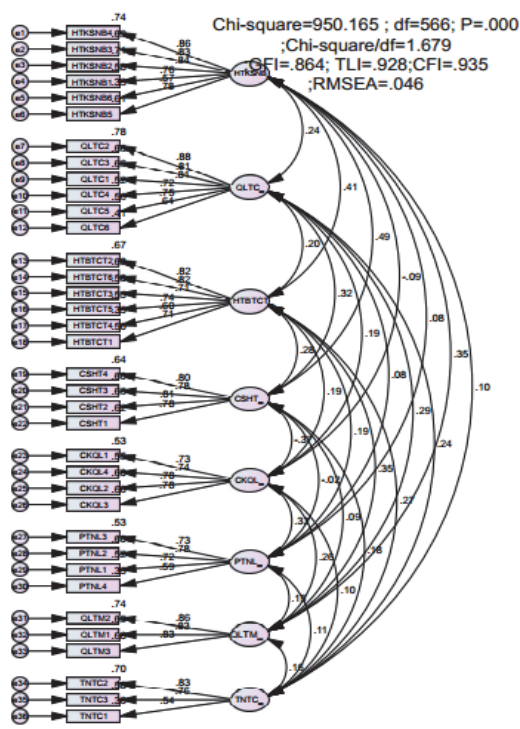

Fig. 3. Confirmed Factors Analysis

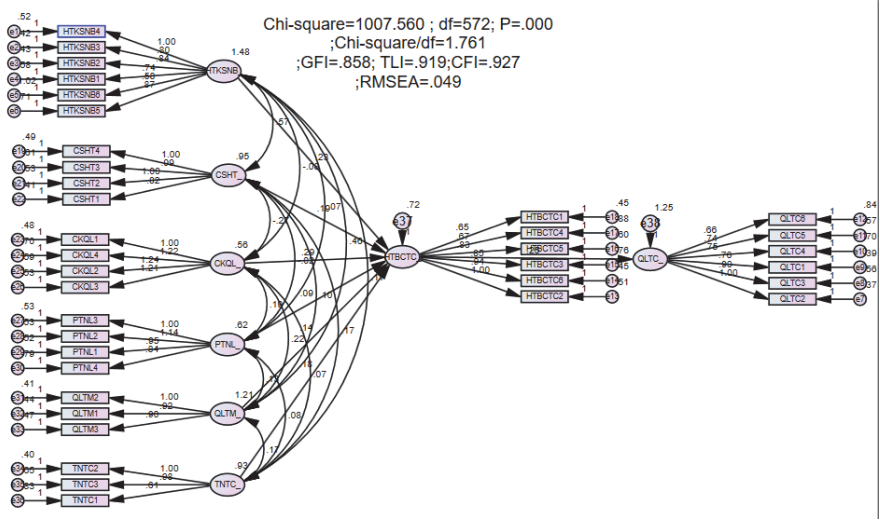

Fig. 4. SEM model test results 
The model has the following measurement values: Chi square $=950.165 ; \mathrm{df}=566 ; \mathrm{P}=0.000 ;$ Chi-squared $/ \mathrm{df}=1,679 ; \mathrm{GFI}$ $=0.864$; TLI $=0.928 ; \mathrm{CFI}=0.935>0.9$; and RMSEA $=0.046<0.05$. Values are within permissible limits (Hair et al., 2010). These model parameters are in accordance with the necessary criteria for CFA; therefore, it can be concluded that the model is consistent with the actual data. Additionally, these data also show that the factors studied in the research model are unidirectional, ensuring the convergent values, ensuring reliability and difference values. The proposed model is consistent with actual data

\subsection{Model of structural SEM equations}

\subsubsection{Model test}

The authors used SEM to evaluate the contribution of each scale, verify the relationship between the conceptual scales and estimate the relationship between the dependent and independent variables (Kline, 2015). SEM also helps to explore measurement errors and incorporate abstract and difficult to distinguish concepts (Anderson \& Gerbing, 1988; Bagozzi \& Foxall, 1996). The values in Fig. 4 show the values in the research model such as: Chi-square $=100,560 ; \mathrm{df}=572 ; \mathrm{P}=0.000 ; \mathrm{Chi}-$ square $/ \mathrm{df}=1.761 ; \mathrm{GFI}=0.858 ; \mathrm{TLI}=0.919 ; \mathrm{CFI}=0.927>0.9$; and $\mathrm{RMSEA}=0.049<0.05$. The model is therefore consistent with the research data

\subsubsection{Bootstrap theoretical model estimation test}

The results in Table 2 include the following values: Average value (Mean), is the regression coefficient of the bootstrap estimate; bias (Bias), which is the difference between the regression column mean and the estimated regression value at runtime without bootstrap; and SE-Bias, which is the standard deviation of the bias, C.R is the weighted ratio.

Table 2

Estimated results Bootstrap

\begin{tabular}{|c|c|c|c|c|c|c|c|c|}
\hline Parameter & & & SE & SE-SE & Mean & Bias & SE-Bias & CR \\
\hline HTBCTC_ & $\leftarrow$ & HTKSNB & 0.080 & 0.003 & 0.279 & 0.005 & 0.004 & 1.25 \\
\hline НТВСТC & $\leftarrow$ & $\mathrm{CSHT}_{-}$ & 0.076 & 0.002 & 0.173 & -0.01 & 0.003 & -3.33 \\
\hline НТВСТC & $\leftarrow$ & $\mathrm{CKQL}_{-}^{-}$ & 0.063 & 0.002 & 0.209 & 0 & 0.003 & 0 \\
\hline HTBCTC_- & $\leftarrow$ & PTNL_ & 0.065 & 0.002 & 0.066 & 0.001 & 0.003 & 0.33 \\
\hline $\mathrm{HTBCTC}_{-}$ & $\leftarrow$ & QLTM_ & 0.068 & 0.002 & 0.157 & 0.005 & 0.003 & 1.67 \\
\hline $\mathrm{HTBCTC}_{-}$ & $\leftarrow$ & $\mathrm{TNTC}_{-}^{-}$ & 0.057 & 0.002 & 0.166 & 0.002 & 0.003 & 0.67 \\
\hline $\mathrm{QLTC}_{-}$ & $\leftarrow$ & HТВС̄̄ & 0.065 & 0.002 & 0.227 & 0 & 0.003 & 0 \\
\hline
\end{tabular}

The absolute CR value is very small compared to 1.96, so it can be said that the bias is very small (corresponding to the normal distribution value at the $5 \%$ significance level). Thus, we can conclude that there is no difference in the estimated value of relationships in the research model before and after running the Bootstrap test. Therefore, the estimate in the theoretical model is reliable.

\subsubsection{Test research model with SEM}

The results shown in Table 3 show statistically significant relationships (p-value $<0.5$ ) for variables affecting financial management, namely: financial reporting system, affected by factors such as: internal control system; Technology infrastructure; Top management commitment; Cash management and budgeting system, Accountability; and financial management, affected by financial reporting system.

Table 3

SEM results test research model

\begin{tabular}{|c|c|c|c|c|c|c|c|c|}
\hline \multicolumn{3}{|c|}{ Structural relationships } & \multirow{2}{*}{$\begin{array}{l}\text { Estimate } \\
.231\end{array}$} & \multirow{2}{*}{$\begin{array}{l}\begin{array}{c}\text { Standardized } \\
\text { estimates }\end{array} \\
0.274\end{array}$} & \multirow{2}{*}{$\begin{array}{l}\text { S.E. } \\
.059\end{array}$} & \multirow{2}{*}{\begin{tabular}{r|} 
C.R \\
3.917
\end{tabular}} & \multirow{2}{*}{$\begin{array}{r}\mathbf{P} \\
* * *\end{array}$} & \multirow{2}{*}{$\begin{array}{r}\text { Hypothesis tes } \\
\text { H1: Acceptable (5\%) }\end{array}$} \\
\hline НTBCTC & $\leftarrow$ & HTKSNB & & & & & & \\
\hline HTBCTC_ & $\leftarrow$ & $\mathrm{CSHT}_{-}$ & .192 & 0.183 & .078 & 2.460 & .014 & H2: Acceptable (5\%) \\
\hline HTBCTC & $\leftarrow$ & $\mathrm{CKQL}_{-}$ & .286 & 0.209 & .099 & 2.879 & .004 & H3: Acceptable ( $1 \%)$ \\
\hline HTBCTC & $\leftarrow$ & PTNL_ & .085 & 0.065 & .082 & 1.044 & .296 & H4:unacceptable (5\%) \\
\hline HTBCTC & $\leftarrow$ & QLTM & .142 & 0.152 & .060 & 2.371 & .018 & H5: Acceptable (5\%) \\
\hline HTBCTC & $\leftarrow$ & TNTC_- $_{-}$ & .175 & 0.164 & .066 & 2.678 & .007 & H6: Acceptable ( 1\%) \\
\hline QLTC & $\leftarrow$ & НТВC̄̄C & .254 & 0.227 & .069 & 3.684 & $* * *$ & H7: Acceptable (1\%) \\
\hline
\end{tabular}

The hypothesis with the highest $\mathrm{P}$ value is hypothesis H5, with p-value of 0.018 and significant significance (with $95 \%$ confidence). 


\section{Discussions on research findings and implications}

\subsection{Discussions on research findings}

The research results show that there are 06 factors affecting the financial reporting system and the financial reporting system that affect the financial management of the unit, specifically:

Firstly, the research hypotheses H1, H2, H3, H5, H6 in the proposed research model are accepted, thus, the factors that have a positive impact on the financial reporting system with the degree of impact Decreasing impact: internal control system $(\beta=$ $0.274)$; Top manager commitment $(\beta=0.209)$; Technology infrastructure $(\beta=0.183)$; Organizational responsibility $(\beta=$ $0.164)$; Cash management and budgeting system $(\beta=0.125)$.

Secondly, financial management is positively affected by the financial reporting system. The research results show that this factor has influenced financial management with the impact level of $\beta=0.227$. This is the first study in Vietnam to use a mixed method of study to find out the relationship of factors affecting the financial reporting system and the financial reporting system affecting financial management in public professional career training and fostering institutions in Ho Chi Minh City in Vietnam. Thus, the factors affecting the financial reporting system, this research result is quite consistent with the study of Diamond \& Khemani (2006), Mwakio (2015), ... when finding impact relationship of internal control system; top managers' commitment; technological infrastructure; organizational responsibility; cash management and budgeting system to financial reporting system. However, if research by Diamond \& Khemani (2006), or Leiderer et al., (2007) finds evidence of the impact of human resource development on the financial reporting system, then This study empirical research results show that this relationship is rejected. The research results also show a difference with comments with the Ministry of Finance of Vietnam (2017), that the human resource factor has a positive influence on the financial reporting system. However, when conducting in-depth interviews with some management experts at the institutions in this study, contrary to the above statement, this is appropriate because the current financial reporting system performs reporting according to the prescribed format and general rules stipulated by the Ministry of Finance.

\subsection{Policy implications}

First, according to research results, the following factors, i.e., internal control system, top managers' commitment, technological infrastructure, organizational responsibility, cash management and budgeting system are among the factors affecting the financial reporting system. Factors of the internal control system, we propose to the management organizations to further strengthen the inspection to reduce fraud; performing regular and continuous monitoring and evaluation. In regard to the top manager's commitment factor, we together propose to equip and use information systems in financial management, resource allocation to implement information systems in financial management. Managers also need to show proactivity by participating in meetings on financial management, training sessions to improve efficiency in financial management. At the same time, managers need to define the goals of the financial management implementation process, clearly define the activities to be performed, and understand the financial management system in the unit. For the work of technology infrastructure, we recommend all units to ensure reliable network connection, invest in equipment, use modern information technology software in accordance with the characteristics of management financial activities of the institutions. Factors of organizational responsibility, we propose that units need to promptly provide relevant information at each stage of financial management, ensuring human resources meet all stages of the financial management process. key, ensuring the unit's information system is always ready to meet all needs of financial management information. In terms of cash management and the budgeting system, we recommend that the organization develop a budget system to ensure that the set targets are met within the scheduled time and these goals should be communicated. timely and accurate reach for user information. Secondly, the research results show that the financial reporting information system affects financial management; therefore, we recommend that the institutions should ensure the quality of information on financial statements must comply with regulations, easy-to-understand, appropriate tables, and accurate reliable data. The qualified financial reporting system will help managers to plan, mobilize, organize use, control and monitor financial resources, and ensure the necessary management information for planning to improve financial management efficiency at the institutions.

\section{References}

Afiah, N.N., \& Azwari, P.C. (2015). The effect of the implementation of government internal control system (GICS) on the quality of financial reporting of the local government and its impact on the principles of good governance: A research in district, city, and provincial government in South Sumatera. Procedia-Social and Behavioral Sciences, 211, $811-818$.

Ahmed, I. H., Babar Z. B., \& Kashif, R. (2010). Financial Management Practices and Their Impact on Organizational Performance, World Applied Sciences Journal, 9 (9), 997-1002.

Allen, R., \& Tommasi, D. (eds) (2001) Managing Government Expenditure: A Reference Book for Transition Countries. Paris: OECD SIGMA. From http://www1.worldbank.org/publicsector/pe/oecdpemhandbook.pdf (viewed: 12.11.2019).

Allis, R. P. M. (2004). Financial management: Ratio analysis zero to one million. New York: McGraw-Hill. 
Anderson, J. C., \& Gerbing, D. W. (1988). Structural equation modeling in practice: A review and recommended two-step approach. Psychological Bulletin, 103(3), 411-423. https://doi.org/10.1037/0033-2909.103.3.411.

Bagozzi, R. P., \& Foxall, G. R. (1996). Construct validation of a measure of adaptive innovative cognitive styles in consumption. International Journal of Research in Marketing, 13(3), 201 - 213.

Bhatia, D. (2003). IFMS Implementation: Aspects for Consideration. World Bank report. Pg 33.

Chado, H., (2015). The effect of integrated financial management information system on the financial management of public sector in Kenya. University of Nairobi. Doctoral dissertation.

Chêne, M., (2009). The Implementation of Integrated Financial Information Management Systems (IFMS), from http://www.u4.no/ helpdesk/helpdesk/query.cfm?id=196 (viewed 06.12. 2019).

COSO (2013). Guidance on Internal Control, from https://www.coso.org/Pages/ic.aspx (viewed 06.12. 2019).

Odoyo, F. S., Adero P., \& Chumba S. (2014). Integrated financial management information system and its effect on cash management in Eldoret West District Treasury, Kenya. International Journal of Business and Social Science, 5(8), 31-37.

Diamond, J. \& Khemani, P., (2006). Introducing Financial Management Information Systems in Developing Countries. OECD Journal on Budgeting. OECD Publishing. Vol. 5(3), 97-132. DOI: 10.1787/budget-v5-art20-en

Department of Education and Training of Ho Chi Minh City (2019), Report data for the education sector, Ho Chi Minh City (Vietnamese).

Dorotinsky, B. (2003). Implemenfing financial management informafion system projects: The World Bank experience, http://blog-pfm.imf.org/AIST2/Dorotinsky.ppt (viewed 12. 04.2019).

Hair Jr., J.F., Black, W.C., Babin, B.J. and Anderson, R.E. (2010). Multivariate Data Analysis: A Global Perspective. 7 th Edition, Pearson Education, Upper Saddle River.

Eton M., Mwosi F., Mutesigensi D., \& Ebong C. D. (2018). The role of financial management in supporting firm growth in Uganda, the Case of West Nile Region. SSRG International Journal of Economics and Management Studies, 5(4), 1-8. DOI: 10.14445/23939125/IJEMS-V5I4P101.

Kline, R. B. (2015). Principles and practice of structural equation modeling. Guilford publications.

Leiderer, S., Hodick, B., Kabey, E., Roll, M., Schnitzer, S., \& Ziegenbein, J., (2007). Public financial management for PRSP implementation in Malawi - Formal and informal PFM institutions in a decentralising system, Studies 28 (2017), Bonn: German Development Institute/Deutsches Institut für Entwicklungspolitik (DIE).

Manh, D. N. \& Thao, N. T. P., (2019), Financial management mechanism at public medical universities in terms of financial autonomy, Financial Journal, http://tapchitaichinh.vn/-business-financial-financial-other-key-financial-companies-infrom-cycle-from-cycle- 313377.html key (viewed 02.3.2020) (Vietnamese).

Minh, V. T \& Huy, N. V., (2018), Some issues on financial management in public universities, Financial Journal, http://tapchitaichinh.vn/nghien-cuu-trao-doi/mot-so-van-de-ve-quan-ly-tai-chinh-tai-cac-truong-dai-hoc-cong-lap-133909.html (viewed 10.4.2020) (Vietnamese).

Mobegi, F. O. (2015). Perceptions of Educational Stakeholders Regarding the Effects of Financial Mismanagement on Physical Facilities in Secondary Schools In Gucha District, Kenya. International Journal of Social Science and Economics Invention, 1(03), 138 - 152. https://doi.org/10.23958/ijssei/vol01-i03/01

Muda, I., Wardani, D. Y., Maksum, A., Lubis, A. F., Bukit, R., \& Abubakar, E. (2017). The influence of human resources competency and the use of information technology on the quality of local government financial report with regional accounting system as an intervening. Journal of Theoretical \& Applied Information Technology, 95(20), 5552-5561.

Mukkamala. H. K., (2013). Critical Success Factors for the Implementation of People Soft Enterprise Resource Planning in a Public Organization, Published by ProQuest LLC.

Mwakio, B. (2015). Challenges Facing County Governments in the Implementation of IFMIS: Case of Taita Taveta County, International Journal of Research in Commerce, Economics \& Management, 5(14), 58 - 61.

National Assembly of Vietnam (2015), Decree No.16/2015/ND - CP dated February 14, 2015 on autonomy mechanism for public organizations, Hanoi (Vietnamese).

Nguyen, T.-L., \& Giang, P.X. (2020). Improving Employee Performance in Industrial Parks: An Empirical Case of Garment Enterprises in Binh Duong Province, Vietnam, European Journal of Investigation in Health, Psychology and Education, 10(1), 44-58. https://doi.org/10.3390/ejihpe10010005

Sánchez, A.A., Marín, G.S., \& Morales, A.M. (2015), The mediating effect of strategic human resource practices on knowledge management and firm performance. Revista Europea de Direccion y Economia de la Empresa, 24 (3), 138148. https://doi.org/10.1016/j.redee.2015.03.003

Simson, R., Saharma, N., \& Aziz, I. (2011). A guide to public financial management literature for practitioners in developing countries, London: Overseas Development Institute.

Tho, N. T., \& Trang, N. T. M. (2011). Brand value in the consumer goods market. In Scientific research in marketing: The application of structure model of SEM. Ho Chi Minh City, Vietnam: Labour Publishing House (Vietnamese).

Thukaram, R. M. (2007). Management accounting. New Delhi: New Age International Publisher

Vietnam Ministry of Finance (2017), Report on Financial Management in Public Educational Institutions in Vietnam, Hanoi (Vietnamese)

Wangari, P, M., \& Muturi, W. (2017). Effects of financial management practices on financial performance of public universities in Kenya, International Journal of Social Sciences and Information Technology, 3(8), 2354 -2363. 
(C) 2021 by the authors; licensee Growing Science, Canada. This is an open access article distributed under the terms and conditions of the Creative Commons Attribution (CC-BY) license (http://creativecommons.org/licenses/by/4.0/). 